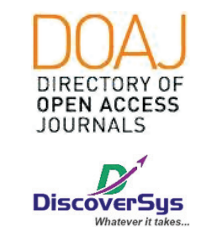

Published by DiscoverSys

\section{Self-esteem formation among people who are in rehabilitation for drug abuse in Bangli Mental Health Hospital, Bali, Indonesia}

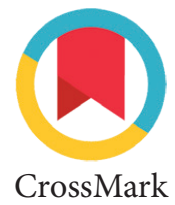

\author{
Mde Dewi Sariyani, ${ }^{1 *}$ Ni Komang Ekawati, ${ }^{1,2}$ \\ Dyah Pradnyaparamita Duarsa, ${ }^{1,2}$ Kadek Sri Ariyanti ${ }^{3}$
}

\title{
ABSTRACT
}

Background: Self-esteem formation is an essential aspect for people who use drugs to support the success of a rehabilitation program, and to prevent ongoing relapse. However, self-esteem formation is not a priority in the rehabilitation program. It also tends to ignore the drug abuse status and psychological states of its clients. This study aimed to explore self-esteem formation among people who are in rehabilitation for drug abuse at the Bangli Mental Health Hospital. Findings from this study provide insights to the hospital on the importance of self-esteem formation through a rehabilitation program.

Metode: A qualitative study was conducted in the Bangli Mental Health Hospital. We recruited a total of ten informants purposively who are in a rehabilitation program for at least two weeks for drug abuse at the Darmawangsa Ward Bangli Mental Health Hospital. Data were collected through in-depth interviews. Data were analyzed inductively and were presented using a narrative approach.

Results: Our in-depth interviews found that self-esteem formation among people who are in rehabilitation for drug abuse depends on various factors such as family support, peer support, life experience, skills and traits, spirituality, policies, parenting history, physical and social environments.

Conclusion: Self-esteem formation is determined by various factors and the drug abuse status of informants. We hope that the Bangli Mental Health Hospital can provide rehabilitation services tailored for every drug abuse status during their recovery time at the rehabilitation center.
${ }^{1}$ Public Health Postgraduate Program, Faculty of Medicine, Udayana University, Bali, Indonesia ${ }^{2} S$ chool of Public Health Faculty of Medicine, Udayana University, Bali, Indonesia

${ }^{3}$ School of Health Science, Advaita Medika Tabanan, Bali, Indonesia

${ }^{*}$ Correspondence to: Mde Dewi Sariyani; Public Health Postgraduate Program, Faculty of Medicine, Udayana University, Bali, Indonesia;

sariyani27@ymail.com

Received: 2019-03-04 Accepted: 2019-08-16 Published: 2019-08-01

Keywords: drug abuse, rehabilitation, self-esteem, the status of drug abuse Cite This Article: Sariyani, M.D., Ekawati, N.K., Duarsa, D.P., Ariyanti, K.S. 2019. Self-esteem formation among people who are in rehabilitation for drug abuse in Bangli Mental Health Hospital, Bali, Indonesia. Intisari Sains Medis 10(3): 477-481. D0I: 10.15562/ism.v10i3.424

\section{INTRODUCTION}

Based on the estimation data in 2014, the prevalence of drug abuse in Indonesia was four million people (2.2\%) of those aged 10-59 years old (184.175.000 people). Bali Province was ranked fourth in Indonesia in 2014 with total drug abusers of 66,785 or equal to $0.02 \%$ from that aged $10-59$ years-old $\left(3,008,900\right.$ people). ${ }^{1}$

Based on the BNNP data in 2016, there was a total of 26 drug-related cases with a total of 30 offenders, where judicial systems have processed a total of 17 cases. $^{2}$ The BNNP Bali has developed a rehabilitation center, however, is limited for outpatient service while for in-patient service is referred to the Bangli Mental Health Hospital. This hospital is a type 'A' and the only hospital that provides a rehabilitation program for drug abuse in Bali Province. $^{3}$

Drug abuse relates not only with physical problems but also psychological issues. ${ }^{4}$ Low self-esteem could lead to depression and drug use. ${ }^{5}$ Psychological training to achieve self-consciousness could enhance rehabilitation outcomes. ${ }^{6}$ Rehabilitation program in Indonesia differs from other countries as it emphasizes the external aspect of the rehabilitation. ${ }^{7}$ In fact, the internal aspect is another important factor in the formation of self-esteem during the recovery period. ${ }^{8}$ The informant status in the Darmawangsa Ward Bangli Mental Health Hospital can be classified into (1) self-referred; (2) prisoners who require rehabilitation; and (3) court decision for rehabilitation. ${ }^{3}$ Based on the aforementioned, this study aimed to explore the internal and external aspects that influence the formation of self-esteem among people who are in rehabilitation for drug abuse.

\section{METHODS}

A qualitative study was conducted between February and April 2017. We selected a total of ten informants using purposive sampling. Inclusion criteria included people who are in rehabilitation at the Darmawangsa Ward Bangli Mental Health Hospital for at least two weeks and agreed to participate in the study. Data were collected through in-depth interview directly by the principal investigator where audio-recorded and transcribed using verbatim approach conducted.

This study aimed to describe self-esteem among informants using the Rosenberg Self-Esteem Scale, together with the informant status and associated internal and external factors that affect self-esteem 
formation. Every item in the Rosenberg Self-Esteem Scale was scored, and the total score was classified into three categories: low self-esteem $(<15)$, moderate self-esteem (15-25), and high self-esteem ( $>25)$. Meanings were revealed through coding and categorization. Responses from the informants were validated through triangulation with health providers who work at the Darmawangsa Ward Bangli Mental Health Hospital (12 nurses). ${ }^{9}$

In-depth interview aimed to explore the internal and external factors that affect the formation of self-esteem among informants. Prior to the data collection, informants have been informed about the nature of the study, and informed consent was obtained before the interview. Data were analyzed using a thematic approach, which involved the identification of themes and categorization of these themes to reveal phenomena. All the results of participants were reported using narrative in order to elaborate on the main findings comprehensively.

\section{RESULTS}

We use narratives and figures to describe the findings. We describe the self-esteem of informants, drug abuse history, and internal and external aspects that affects the formation of self-esteem.

\section{The self-esteem of informants}

We decided to present the self-esteem of informants first before exploring the internal and external factors that affect the formation of self-esteem. We found that six out of ten informants have low self-esteem, and the other four have moderate self-esteem. Those with low self-esteem perceived themselves as an evil (orang jahat), useless (tidak berguna), and a failure (orang gagal). However, informants with moderate self-esteem were appreciated themselves better than those who have low self-esteem. They showed positive attitudes and optimistic, and perceived that they could do good things and useful like others. However, they tend to think that they were not as good as others. The description of the self-esteem of all informants can be seen in Figure 1.

Informants with low self-esteem often perceive themselves as a 'bad person' mirroring the negative attitudes of other people. They also identify themselves as a failure or think about their limitations most of the time. On contrary, informants with moderate self-esteem could enjoy their life with minimum dependency to other people. ${ }^{10}$ This finding is consistent with a theory which explains that those with low self-esteem are more reluctant to accept their weakness or limitation, while those with moderate self-esteem have positive attitudes toward their skills although still think they were not as good as other people.

\section{The informant status and factors associated with self-esteem}

Informants stated that self-esteem is influenced by different aspects, including informant status during rehabilitation (self-referred, prisoner, and court decision). Self-referred informants explained that self-esteem is influenced by life experiences, while prisoners and court decision informants claimed that self-esteem is influenced by their drug abuse experiences, skills, and spirituality.

Self-referred informants also suggest that self-esteem is externally influenced by family support and peer support, while prisoners and court decision informants state that self-esteem is also a product of family and peer support, parenting style, policies/ programs, and physical and social environments.

\section{Internal spirituality}

Spirituality and willingness to connect with 'God' are two main moral support expressed by informants to prevent negative behaviors when they feel disappointed or unsatisfied with their reality. This can be seen in the following quote:

“... spirituality is my foundation to stay positive... When I am in recovery, I just started my pray (or trisandya). Only then I realized that I could be as good as other people" (IN-08, 24 years-old, private worker)

Internal spirituality links with the self-esteem formation among informants. Religiosity has positive effects on the resilience of informants who are under recovery period. ${ }^{11}$ Our finding is consistent with literature which states that internal spirituality encourages informants to think that they can be as good as other people.

\section{Life experiences}

Life experiences affect self-esteem formation because they can learn from these experiences, and life experiences are their strategy to protect themselves from negative events as can be seen from the following quote:

"... I think life experiences are very important; they can act as our protector and teach us for self-respect. We can learn from our past experiences so that we can protect ourselves from negative events" (IN- 02, 33 years-old, owner of private enterprise)

Previous studies suggest that life experiences are important factor for the formation of self-esteem. 


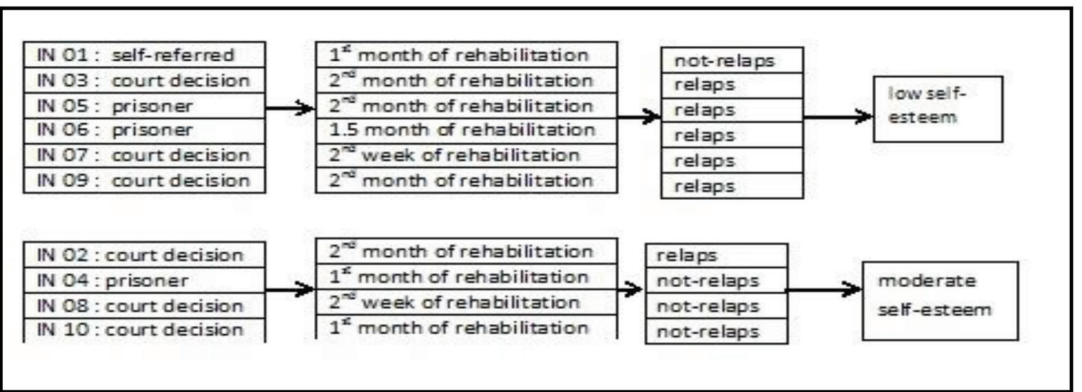

Figure 1 Self-esteem of informants

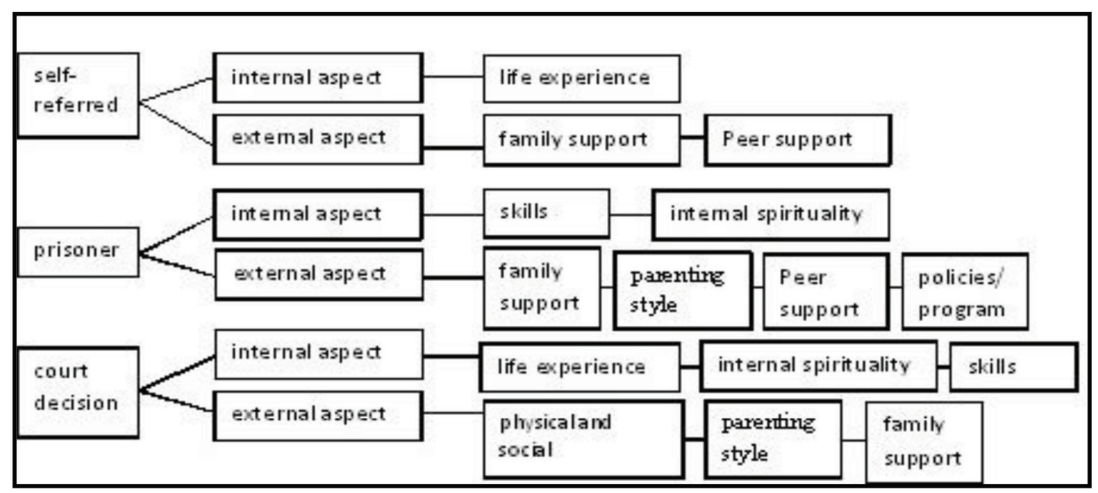

Figure 2 The informant status and factors associated with self-esteem formation

Those who experience many unsatisfied moments in their life tend to relapse easily, and they are strongly attached to drugs. ${ }^{12}$ Our finding is consistent with the previous study, which contends that life experiences could act as a foundation to protect themselves from negative events and teach them for self-respect.

\section{Skills and traits}

Informants suggest that skills and traits are essential aspects of self-esteem formation. They stated that respect and encouragement from other people could boost their self-confidence as can be seen from the following quote:

"... I am proud of myself when I showed my skills to other people, and they respect my skills and assured me that I could be as good as other people" (IN-05, 35 years-old, unemployed)

A study conducted in 2016 found that positive perception regarding their skills could increase the level of self-esteem. ${ }^{13}$ Our finding is consistent with the literature, which suggests that positive encouragements from other people would increase the self-esteem of informants.

\section{Peer Support}

Informants who stay at the same recovery center provide their peer with positive support and encouragement. This is facilitated by the fact that they been through the same journey. An example of peer support received by the informant at the rehabilitation center can be seen from the following quote:

“...I received support from my friends... my family is also supportive... If any of us feel lonely, our friend will approach them and listen to their stories. The main thing is we cannot be alone here..." (IN-05, 35 years-old, security).

A study in 2013 found that support from peers (other people who also use drugs) could facilitate the formation of self-esteem among those who are in rehabilitation for drug abuse. ${ }^{14}$ Our finding is consistent with the previous study, which stated that positive support from peers facilitates the formation of self-esteem. Our informants said that they feel comfortable with the support they received from their peer during their stay at the Darmawangsa Ward Bangli Mental Health Hospital.

\section{Policies and programs}

Every implementation of program is based on the existing policies decided by the program coordinator. Our informants expressed that the existing policies and programs implemented at the Darmawangsa Ward Bangli Mental Health Hospital effectively facilitate the formation of self-esteem, for example the home leave program and family visit policies. These policies effectively assist them to have positive interactions with their families as can be seen in the following quote:

“... Program and policies at this rehabilitation center are really helpful for my self-esteem formation. The center allows me to meet my families... My wife and children are very happy during their visit. I can feel their support" (IN-04, 39 yearsold, farmer)

The previous study found that the expectations of people who use drugs should be taken into account because the fulfillment of these expectations could facilitate the formation of self-esteem. ${ }^{15}$ Our finding is consistent with the previous study, which found that favorable policies at the rehabilitation center can assist the formation of self-esteem of informants, for example the home leave and family visit policies. These are evident that the expectations of informants have been taken into account in the program implementation. Moreover, the implementation of these programs/policies will aid informants to adapt and facilitate the development of self-respect. 


\section{Parenting style}

Parenting style received by informants from their childhood and teenage life influences the formation of self-esteem. Parenting style is strongly attached to informants and will serve as their main foundation for any decision making, as can be seen in the following quote:

".... maybe because my parent spoiled me, I am not afraid to anyone, even when I started using drugs, my parent stayed quiet and never get mad at me" (IN-04, 35 years-old, construction worker)

The previous study found a positive association between authoritative parenting style and resilience of a person. ${ }^{16}$ Our finding is consistent with the previous study which found that the formation of self-esteem among people who are in rehabilitation for drug abuse is influenced by parenting style. Informants stated that they feel uncomfortable with too weak (spoiled) or too strong (very strick) parenting style.

\section{Family support}

Family is the closest relative of the informants. Family support plays a significant role in the formation of self-esteem among people who are using drugs, encouraging them to stop using it. Family support is an important factor for self-esteem formation, as can be seen in the following quote:

".... need the support from my family in order to build my self-confidence or self-esteem... I realized that family is the people that will always be there when you need them while you are happy or sad" (IN-05, security)

Psychology literature suggests that people who use drugs require adequate family support to facilitate recovery from drug addiction..$^{17}$ Our finding is consistent with this literature that family support influences emotional states of informants during the recovery period.

\section{Physical and social environments}

Environments where people live and grow-up determine their character/personality. Informants stated that a peaceful environment and emotionally friendly could facilitate the formation of self-esteem. For example, at the Darmawangsa Ward Bangli Mental Health Hospital, our informants expressed their appreciation of the clean, green, and friendly atmosphere, which are very conducive to their recovery. This can be seen in the following quote:
"....Environments at this center are very conducive for the formation of my self-esteem; the atmosphere is very peaceful and is suitable for rehabilitation. In the past, when I still used drugs, my surroundings were not supported, none quite understood me, maybe because I was influenced by drugs" (IN-09, 40 years-old, security)

A study in 2013 found that social and physical environments where people live and grow were played a crucial role in their mental and character development. ${ }^{18}$ Our finding is consistent with the previous study, which found that a conducive physical and social environment is required to facilitate the formation of self-esteem, especially among those who are in rehabilitation for drug abuse.

The main limitation of this study is that we do not describe the lived experience of informants related to their drug use that may affect the formation of self-esteem. The practical implication of this study is that rehabilitation centers must pay sufficient attention to emotional/psychological states and the status of informants during the recovery period to facilitate the formation of self-esteem. We recommend that the Bangli Mental Health Hospital must take into consideration the internal factors such as psychological or emotional states of informants in the design and implementation of rehabilitation program/policies for drug abuse in order to foster the formation of self-esteem.

\section{CONCLUSION}

Self-esteem formation among patients in the Darmawangsa Ward Bangli Mental Health is limited. The status of informants influences the formation of self-esteem among people who are in the rehabilitation for drug abuse. Different informant status constitutes different internal and external factors that affect the formation processes of self-esteem.

\section{CONFLICT OF INTEREST}

The authors declare that there is no competing interest regarding the manuscript.

\section{ETHICS CONSIDERATION}

The human research ethics committees have approved this study of Sanglah General Hospital Denpasar/Faculty of Medicine Udayana University. 


\section{FUNDING}

The authors are responsible for the funding of study without the involvement of grant, scholarship, or any other resources of funding.

\section{AUTHOR CONTRIBUTION}

All of the authors are equally contributed to the manuscript from the conceptual framework, data gathering, data analysis, until results interpretation in the final report.

\section{ACKNOWLEDGMENTS}

We would like to thank all informants and stakeholders who have supported this study, especially the Bangli Mental Health Hospital for permission to conduct this study.

\section{REFERENCE LISTS}

1. Badan Narkotika Nasional. National Survey on Drugs Abuse in Indonesia. 2014; 4

2. Badan Narkotika Nasional. Cases for Drug Abuse Data. BNNP Bali, 2016.

3. Adi. Preliminary research report of the drug abuse program coordinator of the Bangli Mental Health Hospital. Bali, 2016.

4. Tambunan R. Self-esteem of Teenagers. Informasi Psikolog. Psikologi. 2011

5. Buckner JC, Mandel W. Risk Faktors for Depressive Symptomatology in a Drug Using Population. American Journal of Public Health. 1990;80(5):580-585

6. Winkelman M. Complementary Therapy for Addiction : 'Drumming Out Drugs'. American Journal of Public Health. 2003;93(4):647-651

7. Roberts JC, Wolfer L. Female Drug Offenders Reflect on their Experiences with a County Drug Court Program. Qual Rep 2011;16(1):84-102.
8. Aztri S, Milla MN. Rasa Berharga dan Pembelajaran Hidup Mencegah Kekambuhan Kembali pada Pecandu Narkoba Studi Kualitatif Fenomenologis. Jurnal Psikologi. 2013;9(1):1-16

9. Sutopo HB. Metodologi Penelitian Kualitatif. Universitas Sebelas Maret. Surakarta Sebelas Maret University Press. 2006.

10. Hanur R, Akhmad ARR. Studi perilaku pengguna napza yang di rehabilitasi di Balai Rehabilitasi Tanah Merah, Samarinda, tahun 2014. Kesmas Wigama Jurnal Kesehatan Masyarakat. 2015;1(1):14-17

11. Setiawan A, Pratitis NT. Religiutsitas, Dukungan Sosial dan Resiliensi Korban Lumpur Lapindo Sidoarjo. Persona Jurnal Psikologi. 2015;4(2):137-144.

12. Setiawan HS. Faktor-faktor Penyalahgunaan Narkoba Pada Siswa Sekolah Lanjutan Tingkat Atas. [Thesis]. Universitas Indonesia. 2008

13. Sari EP. Hubungan antara Persepsi terhadap Keterampilan yang Dimiliki Dengan Self Esteem Eks Penyalahguna Napza di Balai Rehabilitasi Sosial Pamardi Putera Lembang. [Skripsi]. Fakultas Psikologi UNISBA. 2016

14. Faulkner A, Sadd J, Hughes A, et al. Mental Health Peer Support in England: Piecing Together The Jigsaw. 2013. [Available at https://www.mind.org.uk/media/5910954/ piecing-together-the-jigsaw-full-version.pdf] [Accessed December $10^{\text {th }} 2018$ ]

15. Ariyani A. Perbedaan Hope dan Self esteem antara Remaja yang Pernah Menggunakan Narkoba dan Remaja yang tidak Menggunakan Narkoba. [Thesis]. Universitas Indonesia Library. 2004

16. Oshel L, Psikologi PS, Kedokteran F, et al. Hubungan antara pola asuh autoritatif dengan resiliensi pada remaja di Denpasar. [Skripsi]. Program Studi Psikologi Universitas Udayana. 2015

17. Gufron MN, Risnawita R. Teori-teori Psikologi. Yogyakarta: Ar-Ruzz Media, 2011.

18. Noviarini NA, Dewi MP, Prabowo H. Hubungan antara Dukungan Sosial dengan Kualitas Hidup pada Pecandu Narkoba yang sedang Menjalani Rehabilitasi. Proceeding PESAT. 2013;5:11-122

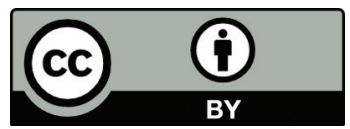

This work is licensed under a Creative Commons Attribution 